\title{
Response of Indian Brown Planthopper, Nilaparvata lugens (Stål) Populations to Crowding
}

\author{
Sunil Vailla ${ }^{1}$, Jhansi Lakshmi Vattikuti ${ }^{1 *}$, Chiranjeevi Konijeti ${ }^{1}$, \\ Sampathkumar Muthuswamy ${ }^{2}$, Rohini Alavala ${ }^{3}$, Jagadish S. Bentur ${ }^{4}$, \\ Chitra Shanker ${ }^{1}$ and G.R. Katti ${ }^{1}$
}

${ }^{1}$ Indian Institute of Rice Research, Rajendranagar, Hyderabad, Telangana. India

${ }^{2}$ National Bureau of Agricultural Insect Resources, Bengaluru, Karnataka, India

${ }^{3}$ Acharya N.G. Ranga Agricultural University, Bapatla, Andhra Pradesh, India

${ }^{4}$ Agri Biotech Foundation, Rajendranagar, Hyderabad, Telangana, India

*Corresponding author

\section{A B S T R A C T}

\begin{tabular}{|l|}
\hline Ke y w o r d s \\
Crowding, \\
Fecundity, \\
Nilaparvata lugens, \\
Nymphal density, \\
Nymphal duration, \\
Populations, Wing \\
dimorphism. \\
\hline Article Info \\
\hline Accepted: \\
17 October 2017 \\
Available Online: \\
10 December 2017
\end{tabular}

\section{Introduction}

Wing dimorphism is a commonly observed phenomenon in insects (Harrison, 1980). The Brown Planthopper, Nilaparvata lugens (Stål) (Hemiptera: Delphacidae) is one of the most serious insect pests of rice in tropical and

\begin{abstract}
Brown planthopper, Nilaparvata lugens (Stål) is a serious pest of rice across the Asian countries. This species exhibits significant wing dimorphism whereby fully developed adults (macropterous forms) are capable of flight. In planthopper species the wing form is determined by a developmental switch that is triggered by environmental factors including crowding, host plant quality, temperature and photoperiod. This study examined the influence of insect density (crowding) on $N$. lugens nymphal survival, nymphal duration, sex ratio, wing dimorphism, adult longevity and fecundity. Response of three BPH populations collected from Nalgonda district of Telangana, West Godavari districts of Andhra Pradesh and Ludhiana of Punjab was observed at four different insect densities i.e., 1, 20, 40 and 60 nymphs/45 days old susceptible variety TN1 plant. High nymphal density/crowding has adversely affected the nymphal survival on $5^{\text {th }}$ and $10^{\text {th }}$ day, nymphal duration, $\%$ adult emergence, sex ratio, adult longevity and fecundity. Nymphal density /crowding has differential influence on sex where more number of winged females and wingless males were observed at high nymphal densities but total brachypterous forms were more at increased nymphal density. Nalgonda population exhibited extreme marcopterous forms, whereas West Godavari and Ludhiana populations showed more brachypterous forms over the broad ranges of nymphal density. Populations responded similarly regarding lower nymphal survival, prolonged nymphal duration, with increasing nymphal density. Among the populations, West Godavari showed lower nymphal survival rate, shorter nymphal duration in males, lower adult longevity but higher fecundity compared to Ludhiana and Nalgonda populations.
\end{abstract}

temperate paddy fields in Asian countries. Adults show wing dimorphism, i.e., long winged macropterous and short winged brachypterous males and females. In planthopper species, the wing form is 
determined by a developmental switch that is triggered by environmental factors including crowding, host plant quality, temperature, and photoperiod (Denno et al., 1985). Macroptery is usually a density-dependent phenomenon but it often increases when host quality declines (Cook and Perfect, 1985). The production of macropters is influenced mostly by nymphal population density (Kisimoto, 1956). From an adaptive viewpoint, it is an advantage to migrate and colonize new habitats when the population density is high and migration requires macroptery. When the population density is low, in contrast, brachyptery is favourable because of their earlier reproduction than macropters (Kisimoto 1956; Denno et al., 1985).

For other delphacid planthopper species, a genetic basis for wing-form determination has been reported for the small brown planthopper, Laodelphax striatetlus (Fallen) (Mahmud, 1980) and Prokelisia marginata (Roderick, 1987). However, genetics of wing form determination is more complex and yet to be resolved. When the population density is low, it is favourable for development of brachypterous forms. This study was undertaken to know if higher nymphal density favours wing development and if all three populations respond to the same extent.

\section{Materials and Methods}

The three populations of Nilaparvata lugens were collected from across the country viz., West Godavari district and Nalgonda districts of Andhra Pradesh state and Ludhiana of Punjab state. The populations were separately reared on young rice seedlings (cv TN1) by Japanese method in flexi cages (Heong et al., 2011) to avoid mating and intermixing of the three populations in the green house at the Indian Institute of Rice Research, Hyderabad, India. 30 gravid females were released in a flexi glass cage for oviposition and were removed after 3 days. The seedlings were allowed for egg hatching for 8-10 days. Newly hatched I instar nymphs were used for this experiment. Four treatments were imposed i.e., 1 nymph/plant, 20 nymphs/ plant, 40 nymphs/plant and 60 nymphs/plant. Desired numbers of nymphs were released on 45 day old susceptible TN1 plants (one plant per test tube) placed in a glass test tube $(25 \times 200 \mathrm{~cm}$ dia) with Hoagland's nutrition media filled upto $5 \mathrm{~cm}$ level. $5 \mathrm{~cm}$ length was marked in the test tube with a marker.

The nymphs were confined within $5 \mathrm{~cm}$ marked area of the test tube by keeping cloth below and above the mark. The nymphs were under crowding condition within $5 \mathrm{~cm}$ gap. When plants showed yellowing symptom due to feeding by nymphs, they were replaced by Plants of the same age. Hoagland solution in the test tube was maintained at the desired level. Observations were recorded on nymphal survival on $5^{\text {th }}$ day and $10^{\text {th }}$ day after release, nymphal duration and no of adults emerged, number of males and females, winged and wingless adults and adult longevity. Fecundity was observed in the surviving adults by releasing them separately.

\section{Data analysis}

Nymphal survival, nymphal duration, percent adult emergence and wing dimorphism were analysed by split plot design to know the interaction between populations and crowding. Longevity and fecundity was analyzed by a General Linear Model (GLM) SYSTAT 12 (Systat software Inc. Chicago IL) with population and crowding included as factors. Datasets were transformed wherever necessary to satisfy assumptions of normality and homogeneity of variances. Where a significant interaction between the two factors occurred in the GLM analysis, a post hoc comparison of means was carried out. The 
Games and Howell method was used to compare means SYSTAT 12 (SYSTAT software Inc. Chicago IL).

\section{Results and Discussion}

\section{Nymphal survival rate on $5^{\text {th }}$ day and $10^{\text {th }}$ day of release}

Across the treatments in West Godavari and Nalgonda populations, 100 percent nymphal survival rate was observed @1nymph/plant density on $5^{\text {th }}$ day and $10^{\text {th }}$ day after release whereas in Ludhiana it was 100 percent on $5^{\text {th }}$ day and 77 percent on $10^{\text {th }}$ day. Population density significantly affected the nymphal survival of West Godavari and Nalgonda $\mathrm{BPH}$ where lower nymphal survival was observed at higher nymphal density (60 nymphs/plant) on both $5^{\text {th }}$ and $10^{\text {th }}$ day after release whereas Ludhiana BPH had not shown significant reduction on $5^{\text {th }}$ day but it was decreased on $10^{\text {th }}$ day.

Across the treatments, nymphal survival rate decreased with increasing nymphal density on both $5^{\text {th }}$ and $10^{\text {th }}$ day after release (Table 1). Among the populations, lowest nymphal survival rate was observed in West Godavari population on $10^{\text {th }}$ day after release compared to Ludhiana and populations. However, there was no significant difference on $5^{\text {th }}$ day after release (Table 1).

\section{Nymphal developmental duration}

West Godavari population showed shorter nymphal duration male and brachypterous male (12.0 days) at lowest nymphal density (1 nymph/plant) compared to other nymphal densities whereas, nymphal density had not shown significant difference in nymphal duration of female, brachypterous female, macropterous female and males. Nymphal density had not influence the nymphal duration of Ludhiana BPH. Nymphal density significantly affected the nymphal duration in females (irrespective of wing forms) in Nalgonda population where prolonged nymphal duration was observed at higher nymphal density (60 nymphs/plant) than at lower nymphal densities $(20$ and 40 nymphs/plant) Whereas in males (irrespective of wing forms) reduced nymphal duration was observed at lower nymphal densities than at other higher nymphal densities (Table 1).

Across the different nymphal densities, population density affected the nymphal duration of BPH where prolonged nymphal developmental duration was observed at higher nymphal density than at lower nymphal densities.

Among the populations, Ludhiana population showed significantly prolonged nymphal duration i.e. 22.3, 18.5, 22.5, 18.2, 18.7, 18.0 days in females, males, brachypterous females and males, macropterous females and males respectively compared to West Godavari and Nalgonda populations.

\section{Nymphal to adult emergence rate}

West Godavari and Nalgonda populations showed 100 percent nymphal to adult emergence at lower nymphal density (1 nymph/plant) compared to Punjab population (44\%). However, adult emergence reduced significantly with increased nymphal densities in all populations.

Across the nymphal densities, highest adult emergence $(81.4 \%)$ was observed at lower nymphal density (1 nymph/plant) and lowest emergence (22.8) was observed at highest nymphal density (60 nymphs/plant). Adult emergence was negatively correlated with nymphal density. Among the populations, it was the lowest in Ludhiana population (20.0 $\%)$ compared to Nalgonda (33.8\%) and West Godavari $(25.9 \%)$ populations. 
Table.1 Effect of nymphal density on nymphal survival, nymphal duration and \% adult emergence of brown planthopper

\begin{tabular}{|c|c|c|c|c|c|c|c|c|c|c|}
\hline \multirow[b]{2}{*}{$\begin{array}{c}\text { Main } \\
\text { treatment } \\
\text { (population) }\end{array}$} & \multirow[b]{2}{*}{$\begin{array}{l}\text { Sub treatment } \\
\text { (Nymphal } \\
\text { density) }\end{array}$} & \multicolumn{2}{|c|}{$\begin{array}{c}\text { Nymphal survival } \\
(\%)\end{array}$} & \multicolumn{6}{|c|}{ Nymph to Adult Developmental Duration(days) } & \multirow[b]{2}{*}{$\begin{array}{c}\text { \%Adult } \\
\text { Emergence }\end{array}$} \\
\hline & & $5 \mathrm{DAR}$ & $\begin{array}{c}10 \\
\text { DAR }\end{array}$ & q & $0^{\lambda}$ & $\mathrm{B}$ 우 & $\mathrm{B}{ }^{\lambda}$ & $\mathrm{M}+$ & $\mathbf{M} \hat{\varnothing}$ & \\
\hline \multirow[t]{4}{*}{ WG } & $\mathrm{T} 1$ & 100.00 & 100.00 & 13.00 & 12.00 & 13.00 & 12.00 & - & 12.00 & 100.00 \\
\hline & $\mathrm{T} 2$ & 88.89 & 50.56 & 13.39 & 13.43 & 13.47 & 13.41 & 13.00 & 13.10 & 26.11 \\
\hline & T3 & 90.28 & 45.00 & 13.46 & 13.29 & 13.46 & 13.35 & - & 13.40 & 21.40 \\
\hline & $\mathrm{T} 4$ & 81.67 & 38.15 & 13.26 & 13.43 & 13.26 & 13.49 & 13.00 & 13.28 & 27.59 \\
\hline \multirow[t]{4}{*}{$\mathrm{LDH}$} & $\mathrm{T} 1$ & 100.00 & 77.78 & 21.00 & 14.00 & 21.00 & 14.00 & - & 20.00 & 44.44 \\
\hline & $\mathrm{T} 2$ & 95.00 & 88.89 & 21.43 & 18.25 & 21.60 & 17.48 & 14.00 & 18.71 & 42.22 \\
\hline & $\mathrm{T} 3$ & 76.11 & 49.44 & 23.71 & 18.90 & 23.86 & 18.53 & 18.00 & 24.00 & 11.4 \\
\hline & $\mathrm{T} 4$ & 79.63 & 64.63 & 22.10 & 19.02 & 22.40 & 19.17 & 20.83 & 18.67 & 17.96 \\
\hline \multirow[t]{4}{*}{ NLG } & $\mathrm{T} 1$ & 100.00 & 100.00 & 12.80 & 13.50 & 12.50 & - & 13.00 & 13.50 & 100.00 \\
\hline & $\mathrm{T} 2$ & 89.40 & 80.00 & 13.52 & 13.47 & 13.85 & 14.33 & 13.42 & 13.43 & 58.33 \\
\hline & T3 & 81.10 & 71.94 & 13.46 & 14.76 & 14.82 & 14.79 & 15.37 & 14.97 & 36.67 \\
\hline & T4 & 76.30 & 60.93 & 15.64 & 14.66 & 15.83 & 14.25 & 15.62 & 14.87 & 22.80 \\
\hline \multirow[t]{2}{*}{$\mathrm{LSD}(\mathrm{P}=0.05)$} & $\begin{array}{c}\text { Population vs } \\
\text { nymphal density }\end{array}$ & NS & 15.00 & NS & 1.35 & NS & 1.35 & NS & 1.49 & 17.32 \\
\hline & $\begin{array}{c}\text { Nymphal } \\
\text { density vs } \\
\text { Population } \\
\end{array}$ & NS & 14.22 & NS & 1.25 & NS & 1.25 & NS & 1.47 & 16.44 \\
\hline \multirow[t]{2}{*}{$\mathrm{LSD}(\mathrm{P}=0.01)$} & $\begin{array}{c}\text { Population vs } \\
\text { nymphal density }\end{array}$ & NS & 20.16 & NS & 1.82 & NS & 1.82 & NS & 2.00 & 23.26 \\
\hline & $\begin{array}{c}\text { Nymphal } \\
\text { density vs } \\
\text { Population } \\
\end{array}$ & NS & 18.87 & NS & 1.66 & NS & 1.66 & NS & 1.96 & 21.83 \\
\hline \multirow{3}{*}{ Populations } & WG & 85.86 & 42.98 & 13.3 & 13.0 & 13.34 & 13.29 & 13.00 & 12.98 & 25.90 \\
\hline & $\mathrm{LDH}$ & 81.18 & 63.73 & 22.3 & 18.5 & 22.51 & 18.20 & 18.75 & 18.02 & 20.00 \\
\hline & NLG & 80.26 & 68.04 & 14.4 & 14.2 & 14.66 & 14.45 & 14.60 & 14.26 & 33.88 \\
\hline $\mathrm{LSD}(\mathrm{P}=0.05)$ & Population & NS & 8.58 & 0.68 & NS & 0.59 & NS & 0.67 & 0.77 & 9.86 \\
\hline $\operatorname{LSD}(\mathrm{P}=0.01)$ & Population & NS & 11.83 & 0.94 & NS & 0.81 & NS & 0.92 & 1.07 & 13.59 \\
\hline \multirow{4}{*}{ Treatments } & $\mathrm{T} 1$ & 100 & 92.59 & 14.67 & 12.67 & 15.51 & 12.67 & 13.00 & 13.40 & 81.48 \\
\hline & $\mathrm{T} 2$ & 91.1 & 73.15 & 14.63 & 13.56 & 16.79 & 15.73 & 13.39 & 14.37 & 42.22 \\
\hline & $\mathrm{T} 3$ & 81 & 54.45 & 18.26 & 15.52 & 18.21 & 15.65 & 15.89 & 15.05 & 23.15 \\
\hline & $\mathrm{T} 4$ & 79.2 & 54.57 & 17.20 & 15.88 & 17.37 & 15.98 & 15.78 & 15.74 & 22.78 \\
\hline $\operatorname{LSD}(\mathrm{P}=0.05)$ & $\begin{array}{l}\text { Nymphal } \\
\text { density }\end{array}$ & 5.06 & 8.21 & 0.74 & 0.72 & 0.75 & 0.72 & 0.78 & 0.85 & 9.49 \\
\hline $\operatorname{LSD}(\mathrm{P}=0.01)$ & $\begin{array}{l}\text { Nymphal } \\
\text { density }\end{array}$ & 6.72 & 10.9 & 0.98 & 0.96 & 0.99 & 0.96 & 1.04 & 1.13 & 12.60 \\
\hline
\end{tabular}

*T1- One Nymph/plant; T2- Twenty Nymphs/plant; T3- Forty Nymphs/plant; T4- Sixty Nymphs/plant

*WG- West Godavari; LDH-Ludhiana; NLG-Nalgonda; DAR-Days after release; + - Female; $\widehat{\partial}$ - Male; $\mathrm{B}$ ㅇ-

Brachypterous female;

$\mathrm{B} \hat{\jmath}$ - Brachypterous male; $\mathrm{M} \propto$ - Macropterous female; $\mathrm{M} \hat{\circ}$ - Macropterous male 
Table.2 Effect of nymphal density on sex ratio and wing dimorphism

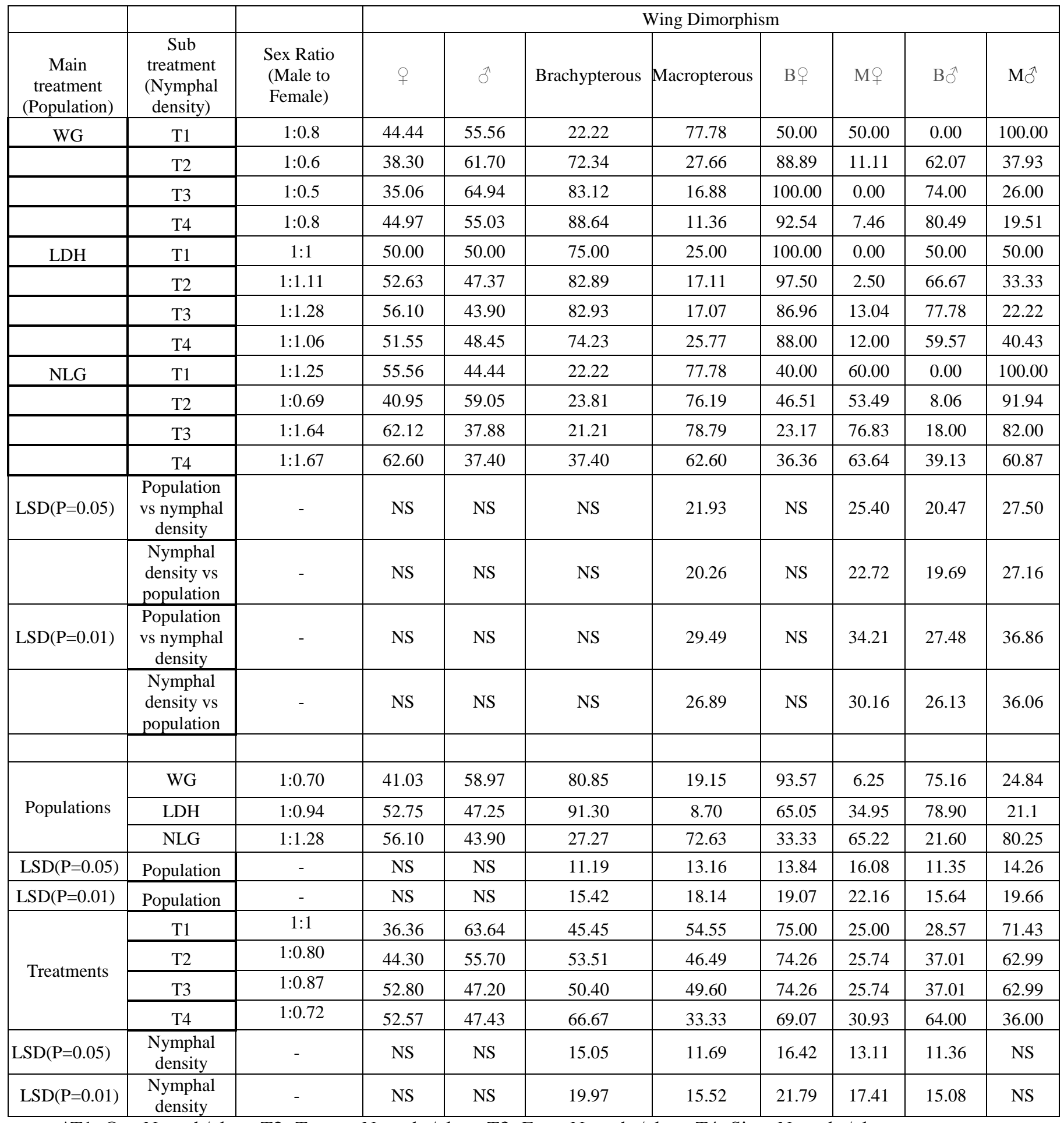

*T1- One Nymph/plant; T2- Twenty Nymphs/plant; T3- Forty Nymphs/plant; T4- Sixty Nymphs/plant.

*WG- West Godavari; LDH-Ludhiana; NLG-Nalgonda; DAR-Days after release; + - Female; $\widehat{\partial}$ - Male; B + -

Brachypterous female;

B $\hat{\jmath}$ - Brachypterous male; $\mathrm{M} \uparrow$ - Macropterous female; $\mathrm{M} \hat{\jmath}$ - Macropterous male 
Table.3 Longevity and fecundity of different brown planthopper populations at different nymphal densities

\begin{tabular}{|l|l|l|l|}
\hline Measurements & Treatments & F-value/ (d.f.) & P-value \\
\hline \multicolumn{2}{|l|}{ Adult longevity } \\
\hline Brachypterous female & West Godavari & $20.704(3)$ & 0.000 \\
\hline & Ludhiana & $4.198(3)$ & 0.01 \\
\hline & Nymphal density & $16.256(3)$ & 0.000 \\
\hline & Population & $0.09(1)$ & 0.76 \\
\hline Macropterous Male & West Godavari & $6.63(3)$ & 0.02 \\
\hline & Ludhiana & $1.53(3)$ & 0.267 \\
\hline & Nalgonda & $5.370(3)$ & 0.002 \\
\hline & Nymphal density & $3.751(3)$ & 0.01 \\
\hline & Populations Fecundity (no of eggs/female) & 0.002 \\
\hline & \multicolumn{1}{|c|}{$6.39(2)$} & 0.000 \\
\hline & West Godavari & $8.516(3)$ & 0.01 \\
\hline & Ludhiana & $4.787(3)$ & 0.02 \\
\hline & Nalgonda & $3.320(3)$ & 0.000 \\
\hline & Nymphal density & $9.86(3)$ & 0.002 \\
\hline & Populations & $6.750(2)$ & \multicolumn{2}{l|}{} \\
\hline
\end{tabular}

Fig.1 Longevity of brachypterous females of BPH populations at different nymphal densities

A

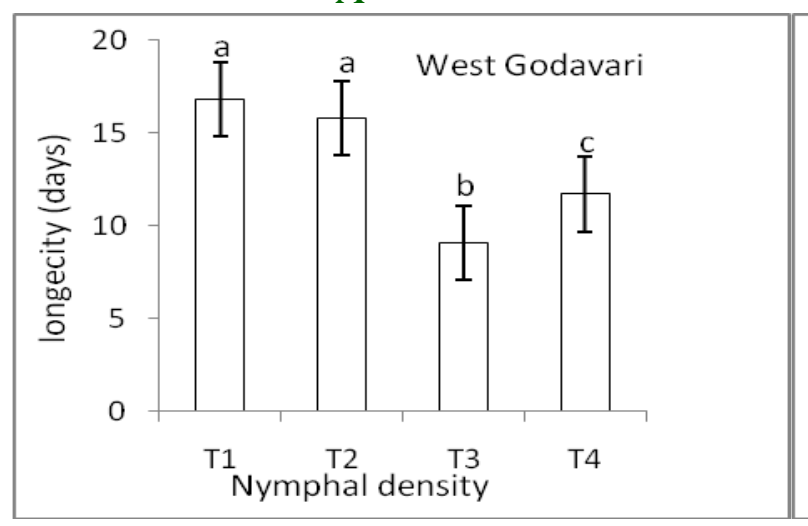

$\mathrm{C}$

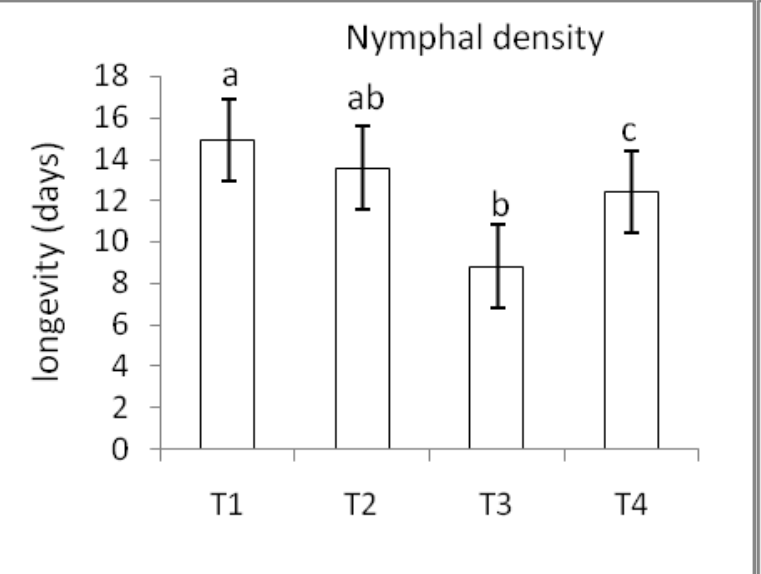

B

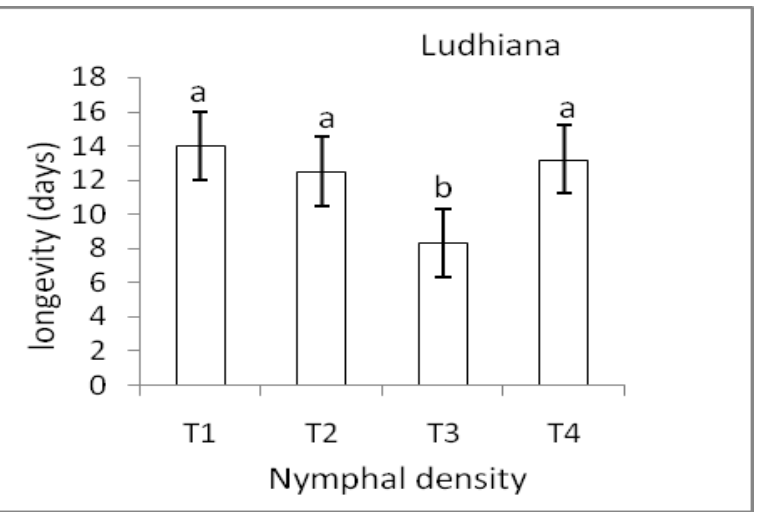

$\mathrm{D}$

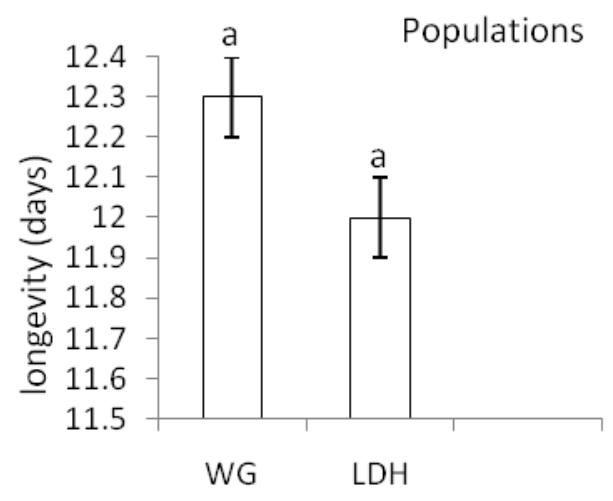

*T1- One nymph/plant; T2- Twenty nymphs/plant; T3- Forty nymphs/plant; T4- Sixty nymphs/plant. WG= West Godavari; LDH= Ludhiana.

Different letters on the bars in a panel denotes significant difference (LSD test, $\mathrm{p}=0.05$ ). 
Fig.2 Longevity of macropterous males of BPH populations at different nymphal densities

A

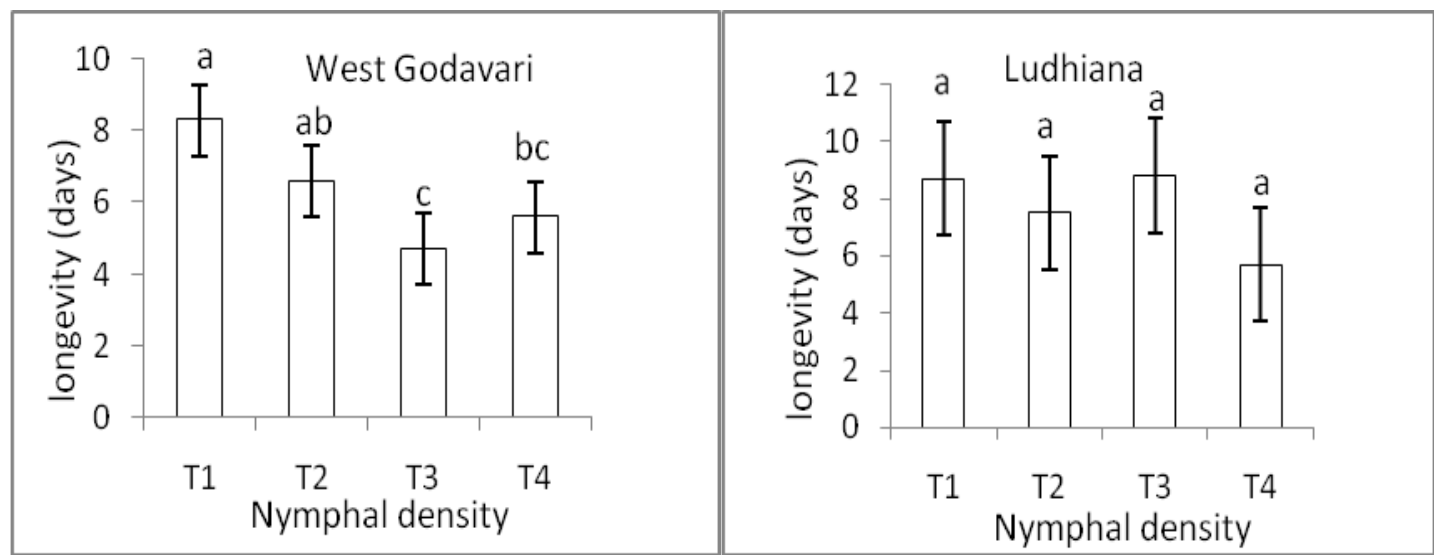

$\mathrm{C}$

$\mathrm{D}$

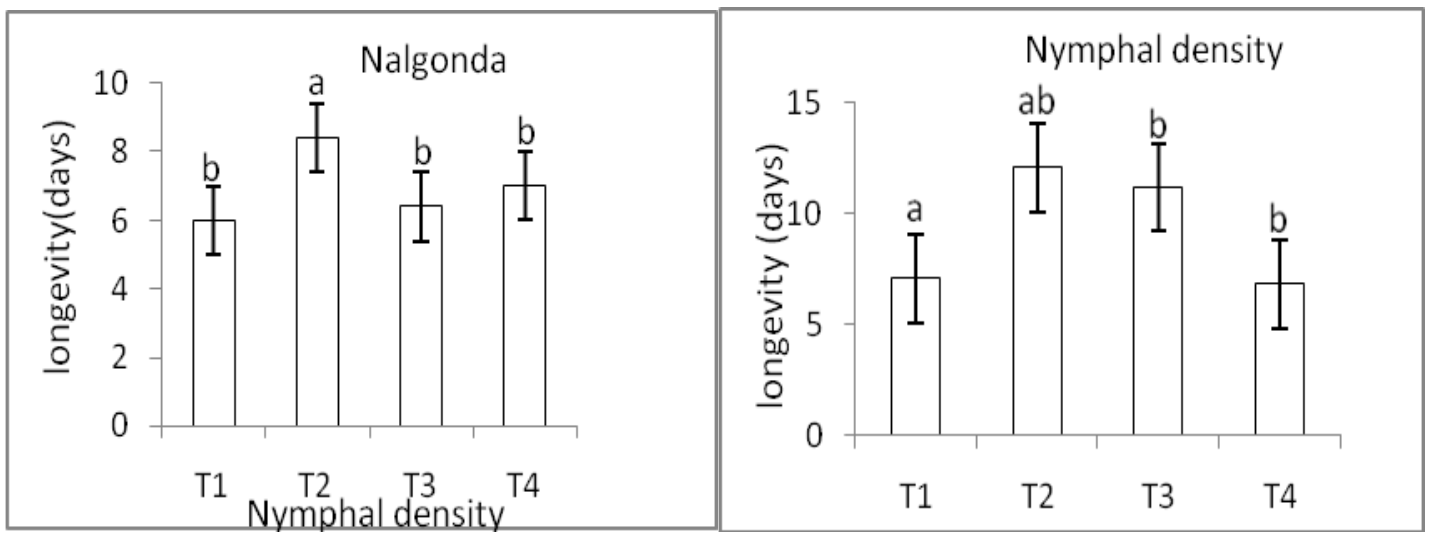

$\mathrm{E}$

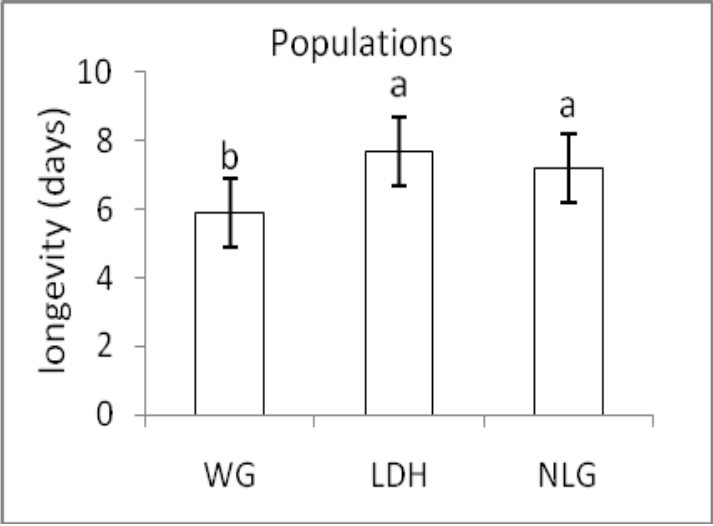

*T1- one nymph/plant; T2-twenty nymphs/plant; T3-forty nymphs/plant; T4-sixty nymphs/plant.

*WG= West Godavari; LDH= Ludhiana; NLG= Nalgonda.

Different letters on the bars in a panel denotes significant difference (LSD test, $\mathrm{p}=0.05$ ). 
Fig.3 Fecundity of three BPH populations at different nymphal densities

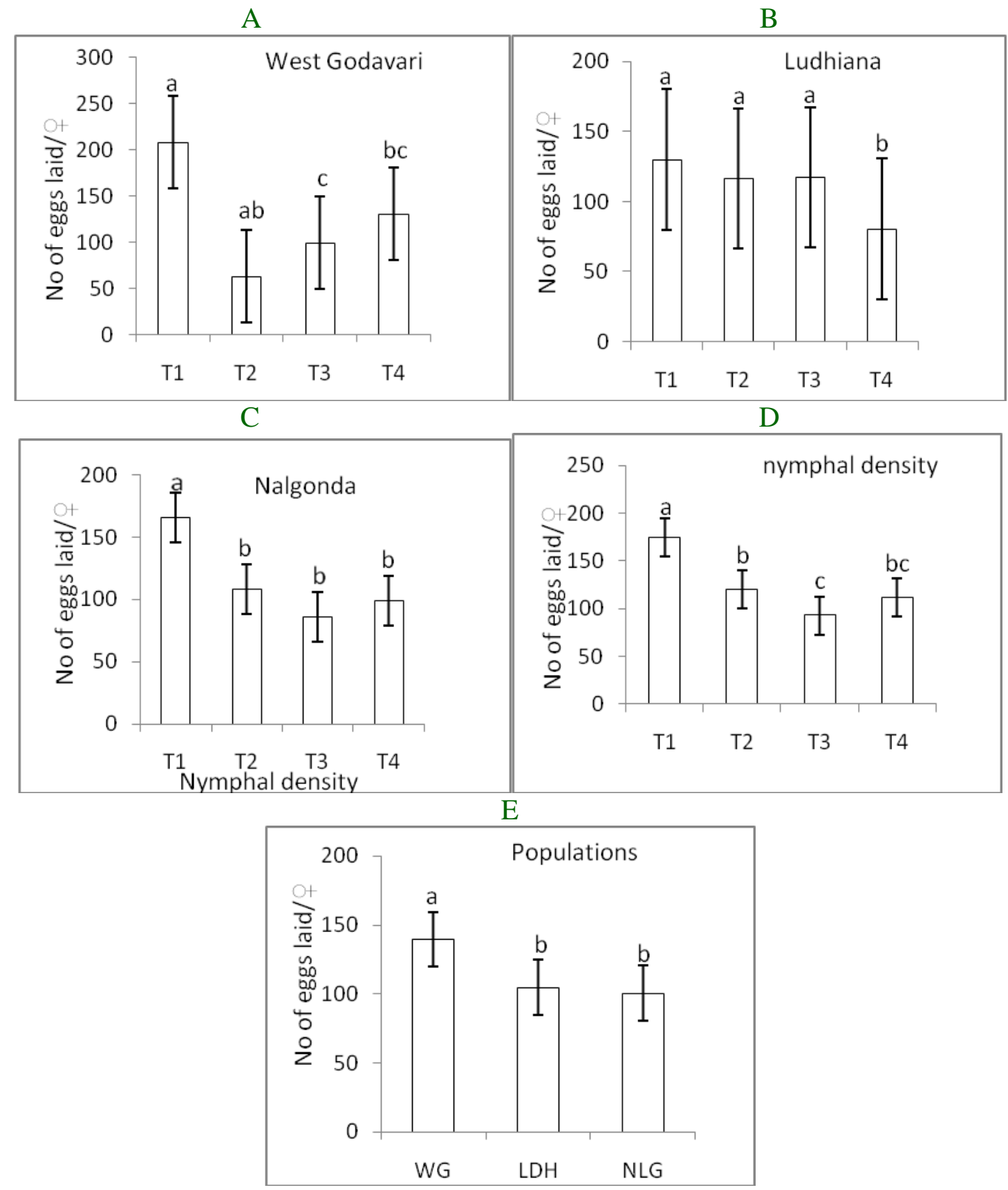

*T1- one nymph/plant; T2-twenty nymphs/plant; T3-forty nymphs/plant; T4-sixty nymphs/plant.

*WG= West Godavari; LDH= Ludhiana; NLG= Nalgonda.

Different letters on the bars in a panel denotes significant difference (LSD test, $\mathrm{p}=0.05$ ).

Sex ratio

West Godavari population showed more no. of males than females across all the densities whereas it was vice versa in Ludhiana and
Nalgonda where more no of females emerged. Across the treatments, more no of males emerged than females at all nymphal densities. Among the populations, Nalgonda showed higher no of females than that of 
West Godavari and Ludhiana populations (Table 2).

\section{Wing dimorphism}

The percent macropterous adults significantly differed among the populations. The macropterous forms emerged in high proportion at all nymphal densities in Nalgonda population. Among the populations, high percentage of macropterous forms were observed in Nalgonda population (72.63) compared to West Godavari (19.15) and Punjab populations (8.70).

In West Godavari and Ludhiana populations, higher percent of brachypterous forms were noticed at all nymphal densities (Table 2). Across the nymphal densities, the percent macroptery was high at lower nymphal densities compared to higher nymphal densities.

\section{Adult longevity}

\section{Brachypterous female}

Lower adult longevity was observed with increasing nymphal density in West Godavari, Ludhiana populations and across the treatments. However, there was no significant difference among the populations. Very few brachypterous females were observed in Nalgonda population (Table 3 and Fig. 1).

\section{Macropterous male}

Adult longevity was highest at lower nymphal density (1 nymph/plant) whereas it was lowest at 40 nymphs/plant in West Godavari population and no significant difference was observed in Ludhiana population. In Nalgonda population, highest adult longevity was observed at 20 nymphs/plant than other nymphal densities. Among the populations, lowest longevity was observed in West
Godavari population compared to Ludhiana and Nalgonda populations (Fig. 2).

\section{Fecundity}

In West Godavari, Nalgonda populations and across the nymphal densities, females emerged at lower nymphal density (1 nymph/plant) laid higher number of eggs compared to those emerged at higher nymphal densities. In Ludhiana population, there was no significant difference among the different nymphal densities. Among the populations, higher fecundity was noticed in West Godavari population compared to Ludhiana and Nalgonda populations (Fig. 3).

Our study demonstrated that nymphal density significantly influenced the biology of brown planthopper.

All the populations responded similarly, where increased nymphal density significantly reduced nymphal survival, number of adults emerged, adult longevity and fecundity and prolonged nymphal duration, at high population densities, intraspecific competition can be intense and adversely affects many components of fitness. When species live under crowded conditions rates of survival are reduced (Denno and Roderick, 1990; Heong, 1988). Kisimoto, (1965) suggested that under crowded conditions individuals develop more slowly and Kenmore, (1980) reported that fecundity is lower because of competition for oviposition sites. Thus high density populations result in decreased reproductive rate (Ro) and population growth (Kuno, 1979).

In planthoppers, wing form is heritable and under polygenic control, but it can be modified substantially by environmental factors (Cook and Perfect, 1985; Iwanaga et al., 1985; Mahmud, 1980; and Mochida, 
1973). Depending on the conditions it experiences as a nymph, an individual can molt into either a macropter or a brachypter. Various environmental cues such as crowding, host plant condition, temperature, and photoperiod act on a hormonal messenger that triggers a developmental switch to determine wing form. The presence of genetically determined brachypterous $N$. lugens populations and whitebacked planthopper, Sogatella furcifera populations was first determined by Nagata and Masuda (1980) in the populations collected in Philippines and Thailand. Recent studies have shown that Indonesian populations showed extremely high proportion of brachyptery under crowding conditions (Nagata, unpublished; Iwanga and Tojo, unpublished)

In our results, high frequency of long winged macropterous forms was observed in Nalgonda population whereas, in West Godavari and Ludhiana, higher percent of brachyptery forms were noticed over the broad range of densities. Within a single species, geographic variation in wing form composition also occurs and results from genetically controlled differences among populations in their response to density (Iwanaga et al., 1985; Iwanaga et al., 1987; and Kisimoto, 1981). Within bush crickets, where populations were under crowding conditions more individuals developed into long winged forms in Metrioptera roeselii, M.brachyptera compared to $M$. roeselii (Fitzgerald and Tipping, 2013). Chu et al., (1982) observed that under crowding conditions, $19 \mathrm{BPH}$ populations showed highly brachypterous and six populations developed into winged forms in a density dependent manner.

Denno and Roderick (1990) reported that atlantic and pacific coast populations of Prokelisia marginata are largely macropterous, whereas Gulf Coast populations are predominantly brachypterous. Differences in host plant persistence, nutritional heterogeneity, and isolation explain the discrepancy in wing form composition among North American populations. Iwanga et al., (1987) reported that some tropical populations of $N$. lugens are predominantly brachypterous; wing form responds weakly to changes in nymphal density and is more influenced by host plant physiology. By contrast, wing form in temperate populations tends to be much more sensitive to density and also observed various responses in the wing form (Macropterous and brachypterous) ratio among the immigrant populations of $N$. lugens. Matsumura, 2002 (unpublished data), investigated the annual variation of density and wing form relationship in the immigrant populations and showed a high ratio of brachypterous females in the $2005 \mathrm{bph}$ population. Under experimental conditions the proportion of the macropterous females can vary from 0 to $100 \%$. Poorer living conditions (e.g. dense populations) during the nymphal stage resulted in more macropterous females. For the male, however, there is apparently an optimum density range that stimulates the appearance of the brachypterous form; the male becomes a macropterous adult at both low and high densities.

In the present study, high nymphal density (crowding) has significantly affected various biological parameters, such as reduced nymphal survival, prolonged nymphal duration, wing dimorphism, reduced longevity and fecundity. Geographical variations were observed in the populations of $N$. lugens collected from Ludhiana, West Godavari and Nalgonda. Among the populations, Ludhiana population was significantly different from other two populations, where prolonged nymphal duration, lower nymphal survival and higher 
brachypterous forms were observed. However, West Godavari population showed reduced adult longevity and higher fecundity whereas in Nalgonda population more number of macropterous forms was observed irrespective of nymphal density. The presence of brachypterous population is to maintain and increase their progenies and macropterous populations to adopt for a migratory life as they predominately produce macropterous forms even at low nymphal density.

\section{Acknowledgments}

The authors are thankful to the "National Innovations on Climate Resilient Agriculture" project funded by ICAR-CRIDA and to the Director, ICAR-Indian Institute of Rice Research and Dr S.R. Voleti PI- NICRA-IIRR for providing facilities.

\section{References}

Chu, Y.I., Kou, R. and Lee, Y.S. 1982. Study on the geographical variations of the brown planthopper, Nilaparvata lugens (Stål) in Taiwan. Chinese Journal of Entomology. 2:155.

Cook, A. G. and Perfect, T. J. 1985. The influence of immigration on population development of Nilaparvata lugens and Sogatella furcifera and its interaction with immigration by predators. Crop Protection. 4: 423-33.

Denno, R. F. and Roderick, G. K. 1990. Population biology of planthoppers. Annual Review of Entomology. 35: 489520.

Denno, R. F., Douglass, L. W. and Jacobs, D. 1985. Crowding and host plant nutrition: environmental determinants of wing-form in Prokelisia marginata. Ecology. 66:1588-96.

Fitzgerald, D. and Tipping, P. W. 2013. Effect of insect density and host plant quality on wing-form in Megamelus scutellaris
(Hemiptera: Delphacidae). Florida Entomologist. 96: 124-130.

Harrison, R. G. 1980. Dispersal polymorphisms in insects. Annual Review of Ecology and Systematics. 11: 95-118.

Heong, K. L. 1988. Effect of adult density on female longevity and oviposition in the rice brown planthopper, Nilaparata lugens (Stål). Journal of Plant Protection in the Tropics. 5:83-86.

Heong, K. L., Tan, K. H., Garcia, C. P. F., Fabellar, L.T. and Lu, Z. 2011. Research methods in toxicology and insecticide resistance monitoring of rice plant hoppers. Los Baños, Philippines, International Rice Research Institute. Pp.101.

Iwanaga, K., Nakasuji, F. and Tojo, S. 1987. Wing dimorphism in Japanese and foreign strains of the brown planthopper, Nilaparvata lugens. Entomologia Experimentalis et Applicata. 43: 3-10.

Iwanaga, K., Tojo, S. and Nagata, T. 1985. Immigration of the brown planthopper, Nilaparvata lugens, exhibiting various responses to density in relation to wingmorphism. Entomologia Experimentalis et Applicata. 35: 101-8.

Jiaan Cheng, Weichun Zhao, Yonggen Lou. and Zhengrong Zhu. 2001. Intra and inter-specific effects of the brown planthopper and whitebacked planthopper on their population performance. Journal of Asia-Pacific Entomology. 4: 85-92.

Kenmore, P. E. 1980. Ecology and outbreaks of a tropical insect pest of the green revolution, the rice brown planthopper, Nilaparvata lugens (Stål). Ph.D thesis. University of California. Berkeley.

Kisimoto, R. 1956. Factors determining the wing-form of adult, with special reference to the effect of crowding 
during the larval period of brown planthopper, Nilaparvata lugens (Stål): studies on the polymorphism in the planthoppers (Homoptera: Araeopidae). Journal of Applied Entomology. 12: 105-111.

Kisimoto, R. 1965. Studies on polymorphism and its role playing in the population growth of the brown planthopper, Nilaparvata lugens (Stål). Bulletin of the shikoku agricultural experiment station. 13: 1-106.

Kisimoto, R. 1981. Development, behaviour, population dynamics and control of the brown planthopper, Nilaparvata lugens (Stål). Journal of Plant Protection Research. 14: 26-58.

Kuno, E. 1979. Ecology of the brown planthopper in temperate regions, brown planthopper: threat to rice production in Asia. Los Baños, Philippines: International Rice Research Institute. Pp. 45-60.

Mahmud, F. S. 1980. Alary polymorphism in the small brown planthopper, Laodelphax striatellus (Homoptera: Delphacidae). Entomologia Experimentalis et Applicata. 9: 444-60.

Mochida, O. 1973. The characters of the two wing-forms of Javesella pellucid (Fabricius) (Homoptera: Delphacidae), special reference to reproduction.
Transactions of the Royal Entomological Society of London, 125:177-225.

Nagata, T. and Masuda, T. 1980. Insecticide susceptibility and wing form ratio of the brown planthopper, Nilaparvata lugens (Stål) (Hemiptera: Delphacidae) and whitebacked planthopper, Sogatella furcifera (Horvath) (Hemiptera: Delphacidae) of Southeast Asia. Applied Entomology and Zoology.15: 10-19.

Paguia, P., Pathak, M. D. and Heinrichs, E. A. 1980. Honeydew excretion measurement techniques for determining differential feeding activity of biotype of Nilaparvata lugens on rice varieties. Ecological Entomology. 73: 35-40.

Roderick, G. K. 1987. Ecology and evolution of dispersal in Californian populations of a salt marsh insect, Prokelisia marginata. Ph.D thesis. University of California. Berkeley.

Vasanta Bhanu, K., Jhansi Lakshmi, V., Katti, G. and Vishnuvardhan Reddy, A. 2014. Antibiosis and tolerance mechanisms of resistance in rice varieties carrying brown planthopper resistant genes. Asian Journal of Biological and Life Sciences. 3: 108-113.

\section{How to cite this article:}

Sunil Vailla, Jhansi Lakshmi Vattikuti, Chiranjeevi Konijeti, Sampathkumar Muthuswamy, Rohini Alavala, Jagadish S. Bentur, Chitra Shanker and Katti, G.R. 2017. Response of Indian Brown Planthopper, Nilaparvata lugens (Stål) Populations to Crowding. Int.J.Curr.Microbiol.App.Sci. 6(12): 2147-2158. doi: https://doi.org/10.20546/ijcmas.2017.612.247 